\title{
PENGARUH BOKASHI TERHADAP PERTUMBUHAN BAYAM CABUT (Amaranthus tricolor L.)
}

\section{THE EFFECT OF BOKASHI ON GROWTH OF SPINACH (Amaranthus tricolor L.)}

\author{
Ahmad Raksun *, Wayan Merta, I Gde Mertha dan Liwa Ilhamdi \\ Program Studi Pendidikan Biologi FKIP Universitas Mataram, Mataram, Indonesia \\ Email: ahmadunram@unram.ac.id
}

Diterima: 21 Juli 2020. Disetujui: 23 Juli 2020. Dipublikasikan: 30 September 2020

\begin{abstract}
Abstrak: Bayam adalah bahan sayuran yang bergizi tinggi. Pertumbuhan bayam ditentukan oleh ketersediaan unsur hara pada lahan pertanian. Pemupukan merupakan salah satu upaya yang dapat dilakukan untuk meningkatkan ketersediaan unsur hara. Telah dilakukan penelitian tentang aplikasi bokashi untuk meningkatkan pertumbuhan bayam cabut di Desa Bajur Kabupaten Lombok Barat. Penelitian ini bertujuan untuk mengetahui (1) pengaruh bokashi terhadap pertumbuhan bayam cabut, (2) Dosis optimum bokashi untuk meningkatkan pertumbuhan bayam cabut. Dalam penelitian ini digunakan Rancangan Acak Lengkap dengan 6 ulangan. Perlakuan bokashi terdiri atas 6 level, yaitu: $\mathrm{B}_{0}=$ tampa pemberian bokashi (kontrol), $\mathrm{B}_{1}=$ pemberian $0.4 \mathrm{~kg}$ bokashi10 $\mathrm{kg}$ tanah, $\mathrm{B}_{2}=$ pemberian $0.8 \mathrm{~kg}$ bokashi $/ 10 \mathrm{~kg}$ tanah, $\mathrm{B}_{3}=$ pemberian $1.2 \mathrm{~kg}$ bokashi $/ 10 \mathrm{~kg}$ tanah, $\mathrm{B}_{4}$ $=$ pemberian $1.6 \mathrm{~kg}$ bokashi $/ 10 \mathrm{~kg}$ tanah, $\mathrm{B}_{5}=$ pemberian $2.0 \mathrm{~kg}$ bokashi $/ 10 \mathrm{~kg}$ tanah. Parameter pertumbuhan yang diukur adalah tinggi batang, panjang daun, lebar daun, jumlah daun dan diameter batang yang diukur pada umur 18 hari setelah tanam Hasil penelitian menunjukkan bahwa: (1) pemberian bokashi berpengaruh nyata terhadap tinggi batang, panjang daun, lebar daun dan diameter batang tetapi tidak berpengaruh nyata terhadap jumlah daun bayam cabut, (2) dosis optimum bokashi untuk meningkatkan pertumbuhan bayam cabut adalah 1.6 $\mathrm{kg}$ per $10 \mathrm{~kg}$ tanah.
\end{abstract}

Kata kunci: Bokashi, pertumbuhan bayam cabut.

Abstract: Spinach is a nutritious vegetable ingredient. Spinach growth is determained bay the availability of nutrients on agricultural land. Fertilization is one of the efforts that can be done to increase the availability of nutrient. Research has been done on the application of bokashi to increase the growth of spinach in Bajur Village, West Lombok Regency. This research aims to determine (1) the influence of bokashi on the growth of spinach, (2) the optimum dose of bokashi to increase the growth of spinach. In this study used a completely randomized design with 6 replication. Treatment of bokashi consists of 6 levels, namely: $\mathrm{B}_{0}=$ wihout giving bokashi, $\mathrm{B}_{1}=$ giving $0.4 \mathrm{~kg}$ bokashi $/ 10 \mathrm{~kg}$ of soil, $\mathrm{B}_{2}=$ giving $0.8 \mathrm{~kg}$ bokashi $/ 10 \mathrm{~kg}$ of soil, $\mathrm{B}_{3}=$ giving $1.2 \mathrm{~kg}$ bokashi $/ 10 \mathrm{~kg}$ of soil, $\mathrm{B}_{4}=$ giving $1.6 \mathrm{~kg}$ bokashi $/ 10 \mathrm{~kg}$ of soil, $\mathrm{B}_{5}=$ giving $2.0 \mathrm{~kg}$ bokashi $/ 10 \mathrm{~kg}$ of soil. The growth parameters were steam height, leaf length, leaf width, number of leaves and stem diameter measured at 18 days after planting. The results showed that: (1) bokashi application significantly influences stem height, leaf length, leaf width, and stem diameter but does not affect the number of spinach leaves, (2) optimum dosage of bokashi to increase the growth of spinach is $1,6 \mathrm{~kg} / 10 \mathrm{~kg}$ of soil

Keywords: bokashi, growth of spinach.

\section{PENDAHULUAN}

Bayam merupakan bahan sayuran daun yang bergizi tinggi dan digemari oleh semua lapisan masyarakat. Bayam merupakan bahan pangan sumber protein, vitamin A dan $\mathrm{C}$ serta sedikit vitamin $\mathrm{B}$ dan mengandung garam-garam mineral seperti kalsium, fospor, dan besi. Bayam telah lama dikenal dan dimanfaatkan oleh masyarakat Indonesia. Daun bayam dapat dibuat berbagai macam sayur mayur. Bayam juga memiliki beberapa manfaat diantaranya dapat memperbaiki daya kerja ginjal dan melancarkan pencernaan [15].

Pertumbuhan tanaman bayam sangat ditentukan oleh ketersediaan unsur hara pada lahan pertanian. Upaya meningkatkan ketersediaan unsur hara pada lahan pertanian dapat dilakukan dengan pemupukan. Pada saat ini sebagian besar petani khususnya di Pulau Lombok melakukan pemupukan tanaman menggunakan pupuk sintetik seperti pupuk urea dan atau pupuk NPK. [18] menjelaskan bahwa aplikasi input kimiawi yang berupa pupuk dan festisida sintetik dengan dosis tinggi tidak hanya berpengaruh menurunkan tingkat kesuburan tanah, tetapi juga mengakibatkan pada merosotnya keanekaragaman hayati, meningkatnya serangan hama dan penyakit, timbulnya hama yang resisten dan berkembangnya organisme parasit. Selain itu dampak negatif dari penggunaan input kimiawi tidak hanya terbatas pada daerah pemakaian tetapi dapat menjadi makin luas melalui komponen rantai makanan seperti air minum, sayuran, buah-buahan dan produk-produk lain yang terkontaminasi.

Selain menggunkan pupuk sintetik, pemupukan tanaman dapat juga dilakukan dengan mengunakan pupuk organik. Penggunaan pupuk organik memiiki berbagai keunggulan dibandingkan pupuk kimia 
diantaranya dapat mengatur sifat tanah dan dapat berperan sebagai penyangga persediaan unsur hara bagi tanaman sehingga pupuk ini dapat mengembalikan kesuburan tanah [17]. Salah satu pupuk organik yang dapat digunakan untuk meningkatkan pertumbuhan tanaman adalah pupuk organik bokashi. Pemupukan tanaman menggunakan bokashi sudah dilakukan pada sejumlah tanaman. Pemberian bokashi berpengaruh nyata terhadap pertumbuhan kacang panjang [8]. Pemupukan menggunakan bokashi berpengaruh signifikan terhadap produksi cabai rawit, kadar optimum bokashi yang perlu diberikan pada lahan pertanian agar cabai rawit berproduksi secara optimal adalah 1,0 kg untuk setiap $10 \mathrm{~kg}$ tanah [10]. Pemupukan bokashi dengan dosis 20 ton per hektar memberikan bobot gabah kering per hektar tertinggi (4,70 ton), jumlah anakan produktif tertinggi $(25,00)$ dicapai varietas cianjur [5]. Perbedaan Dosis bokashi berpengaruh nyata terhadap tinggi batang, panjang helaian daun, dan berat basah batang cabai rawit [12]. Pemberian pupuk bokashi Eceng Gondok menunjukkan respon sangat nyata pada total produksi kedelai per plot [3].

Berdasarkan uraian di atas maka peneliti melakukan penelitian tentang aplikasi bokashi untuk meningkatkan pertumbuhan vegetatif bayam cabut. Adapun tujuan penelitian ini adalah untuk mengetahui: (1) pengaruh aplikasi bokashi terhadap pertumbuhan vegetatif bayam cabut putih. (2) kadar optimum bokashi yang perlu diberikan pada lahan pertanian agar tanaman bayam cabut dapat tumbuh secara optimal.

\section{BAHAN DAN METODE}

Penelitian ini sudah dilaksanakan di Desa Bajur Kecamatan Labuapi Kabupaten Lombok Barat. Bahan-bahan yang digunakan dalam penelitian ini adalah benih bayam cabut putih, tanah sawah, air, bokashi, insektisida, hebisida, pot plastik dan fungisida. Selanjutnya alat yang digunakan adalah artco dorong, ember plastik, parang, palu, cangkul, timbangan, alat tulis menulis, meteran, gunting, karung nilon, gembor, sekop, cangkul dan hand sprayer.

Dalam penelitian ini digunakan rancangan acak lengkap. Perlakuan bokashi terdiri atas 6 level, yaitu: $\mathrm{B}_{0}=$ tampa pemberian bokashi (kontrol), $\mathrm{B}_{1}=$ pemberian $0.4 \mathrm{~kg}$ bokashi $/ 10 \mathrm{~kg}$ tanah, $\mathrm{B}_{2}=$ pemberian $0.8 \mathrm{~kg}$ bokashi $/ 10 \mathrm{~kg}$ tanah, $\mathrm{B}_{3}=$ pemberian $1.2 \mathrm{~kg}$ bokashi $/ 10 \mathrm{~kg}$ tanah, $\mathrm{B}_{4}=$ pemberian $1.6 \mathrm{~kg}$ bokashi $/ 10 \mathrm{~kg}$ tanah, $\mathrm{B}_{5}=$ pemberian $2.0 \mathrm{~kg}$ bokashi/10 $\mathrm{kg}$ tanah. Setiap perlakuan dilakukan dengan enam ulangan sehingga diperoleh $6 \times 6=36$ unit percobaan.

Pada penelitian ini, media tanah dikeringkan pada terik matahari kemudian dibersihkan dari sampah dan kerikil dan diayak dengan ayakan bermata ayak $0.5 \mathrm{~cm}$. Selanjutnya media tanah diletakkan didalam pot plastik. Setiap pot plastik diisi dengan $10 \mathrm{~kg}$ tanah. Masing-masing pot percobaan diberi perlakuan bokashi sesuai dosis percobaan. Pada masing-masing pot percobaan ditanam 10 benih tanaman bayam putih yang dilakukan setelah 25 hari perlakuan bokashi. Setelah tanaman berumur 8 hari dilakukan penjarangan. Pada masing-masing pot disisakan hanya satu tanaman bayam cabut putih yang ukurannya homogen untuk seluruh unit percobaan.

Parameter pertumbuhan yang diukur adalah tinggi batang, panjang daun, lebar daun, jumlah daun dan diameter batang yang diukur pada umur 18 hari setelah tanam. Data kuantitatif hasi pengukuran parameter di atas dianalisis dengan analisis sidik ragam $[2,16]$.

\section{HASIL DAN PEMBAHASAN}

Data hasil pengukuran parameter pertumbuhan yang meliputi tinggi batang, jumlah daun, panjang daun, lebar daun dan diameter batang tanaman bayam cabut putih memperlihatkan adanya variasi sesuai dosis perlakuan. Data hasil pengukuran tinggi batang tanaman bayam terdapat pada gambar 1 .

Data pada gambar 1 menunjukkan bahwa rerata tinggi batang tanaman bayam cabut tertinggi adalah $22 \mathrm{~cm}$ terdapat pada perlakuan $\mathrm{B}_{4}$ (perlakuan $1,6 \mathrm{~kg}$ bokashi per $10 \mathrm{~kg}$ tanah). Selanjutnya rerata tinggi batang bayam cabut terendah adalah $17 \mathrm{~cm}$ terdapat pada perlakuan $\mathrm{B}_{0}$ dan $\mathrm{B}_{1}$ (perlakuan $0 \mathrm{~kg}$ dan $0,4 \mathrm{~kg}$ bokashi per $10 \mathrm{~kg}$ tanah). Hasil analisis sidik ragam pengaruh aplikasi bokashi terhadap tinggi batang bayam disajikan pada tabel 2 .

Hasil analisis sidik ragam pengaruh aplikasi bokashi terhadap tinggi batang bayam cabut pada tabel 2 menunjukkan bahwa aplikasi bokashi berpengaruh nyata terhadap tinggi batang tanaman bayam cabut. Selanjutnya data rerarata jumlah daun bayam akibat perbedaan dosis bokashi yang diukur 18 hari setelah tanam disajikan pada gambar 2 .

Pada gambar 2. nampak bahwa jumlah helaian daun tanaman bayam cabut tertinggi adalah 6 helai daun terdapat pada perlakuan $\mathrm{B}_{0}, \mathrm{~B}_{1}$ dan $\mathrm{B}_{5}$ (perlakuan $0 \mathrm{~kg}, 0,4 \mathrm{~kg}$ dan $2 \mathrm{~kg}$ bokashi per $10 \mathrm{~kg}$ tanah). Jumlah daun terendah adalah 5 helai terdapat pada perlakuan $B_{2}, B_{3}$ dan $B_{4}$. Selanjutnya hasil analsis sidik ragam pengaruh aplikashi bokashi terhadap jumlah daun tanaman bayam cabut terdapat pada tabel 2 .

Hasil analisis sidik ragam pengaruh dosis bokashi terhadaap jumlah daun tanaman bayam cabut menunjukkan bahwa perbedaan dosis bokashi tidak berpengaruh nyata terhadap jumlah helaian daun tanaman bayam cabut. Selanjutnya data hasil pengukuran panjang daun bayam cabut terdapat pada gambar 3.

Pada gambar 3 disajikan bahwa rerata panjang helaian daun bayam cabut tertinggi adalah $66 \mathrm{~mm}$ terdapat pada perlakuan $\mathrm{B}_{4}$ dan $\mathrm{B}_{5}$ (perlakuan $1,6 \mathrm{~kg}$ dan $2.0 \mathrm{~kg}$ bokashi per $10 \mathrm{~kg}$ tanah). Panjang helaian daun terendah terdapat pada perlakuan $\mathrm{B}_{0}$ (perlkuan $0 \mathrm{~kg}$ bokashi per $10 \mathrm{~kg}$ tanah). Hasil analisis sidik ragamnya disajikan pada tabel 3 . 
Tabel 1. Hasil Analis Sidik Ragam Pengaruh Bokashi terhadap Tinggi Batang Bayam Cabut pada Umur 18 HST

\begin{tabular}{lccccc}
\hline \multicolumn{1}{c}{ SK } & DB & JK & KT & F. Hit & F tabel 5\% \\
\hline Perlakuan & 5 & 111.6 & 22.3 & 17.31 & 2.42 \\
Galat & 30 & 38.7 & 1.3 & & \\
Umum & 35 & 150.2 & 4.3 & & \\
\hline
\end{tabular}

Tabel 2. Hasil Analisis Sidik Ragam Pengaruh Bokashi terhadap Jumlah daun Bayam Cabut pada umur 18 HST

\begin{tabular}{lccccc}
\hline \multicolumn{1}{c}{ S K } & DB & JK & KT & F. Hit & F tabel 5\% \\
\hline Perlakuan & 5 & 2.56 & 0.51 & 2.32 & 2.42 \\
Galat & 30 & 6.67 & 0.22 & & \\
Umum & 35 & 9.22 & 0.26 & & \\
\hline
\end{tabular}

Tabel 3. Hasil Analisis Sidik Ragam Pengaruh Bokashi terhadap Panjang Daun Bayam cabut pada umur 18 HST

\begin{tabular}{lccccc}
\hline \multicolumn{1}{c}{ S K } & DB & JK & KT & F. Hit & F tabel 5\% \\
\hline Perlakuan & 5 & 188.6 & 37.7 & 28.28 & 2.42 \\
Galat & 30 & 40 & 1.3 & & \\
Umum & 35 & 228.6 & 6.5 & & \\
\hline
\end{tabular}

Tabel 4. Hasil Analisis Sidik Ragam Pengaruh Dosis Bokashi terhadap Lebar Helaian Daun Bayam Cabut

\begin{tabular}{cccccc}
\hline SK & DB & JK & KT & F. Hit & F tabel 5\% \\
\hline Perlakuan & 5 & 56.6 & 11.3 & 17.25 & 2.42 \\
Galat & 30 & 19.7 & 0.7 & & \\
Umum & 35 & $76, .2$ & 2.2 & & \\
\hline
\end{tabular}

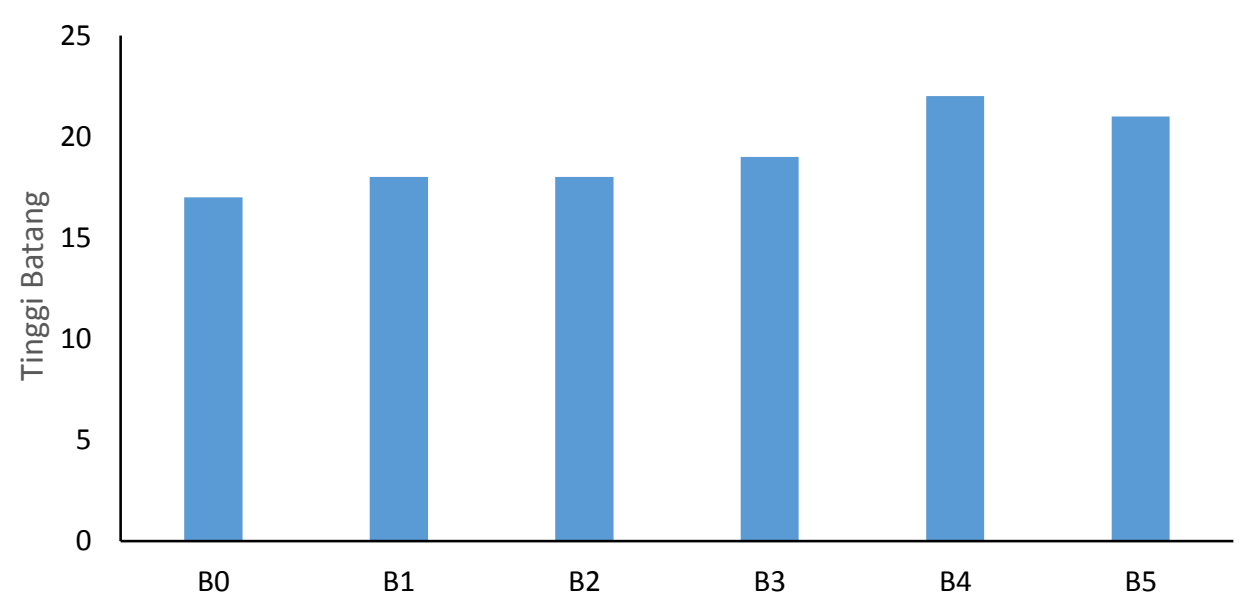

Gambar 1. Rerata Tinggi Batang (cm) tanaman Bayam Cabut 


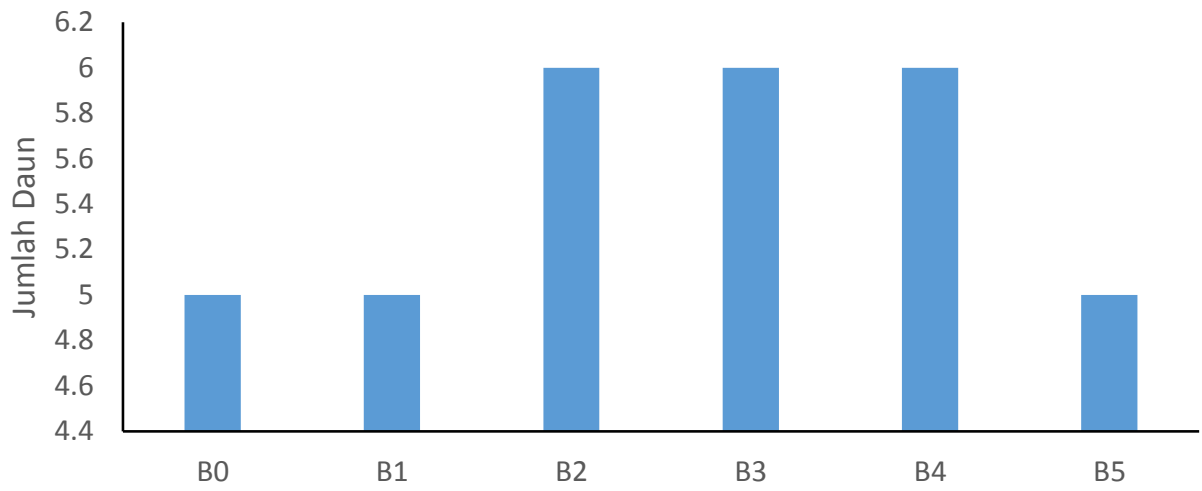

Gambar 2. Rerata Jumlah Daun (helai) Bayam Cabut

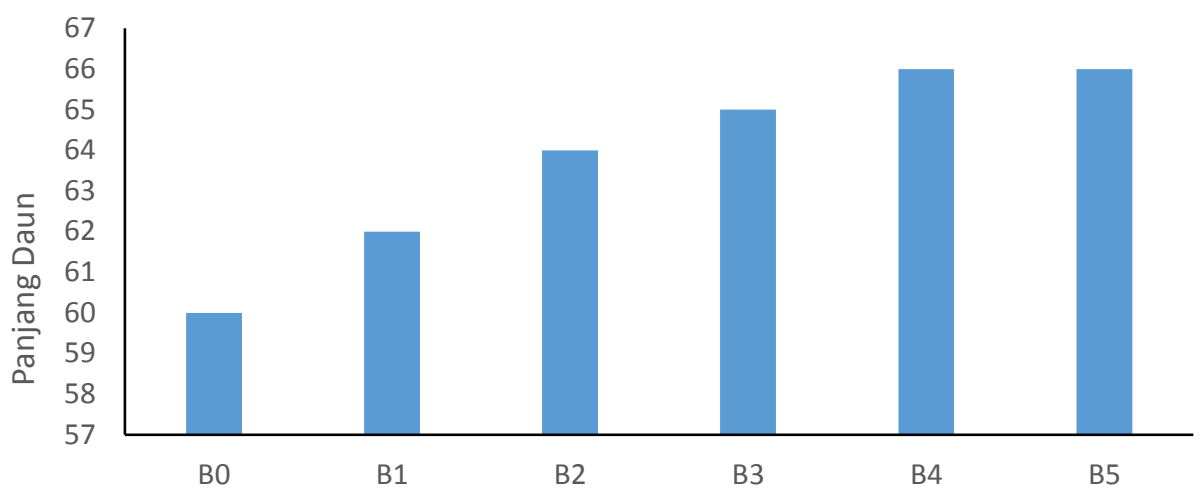

Gambar 3. Rerata Panjang Daun Bayam Cabut (mm)

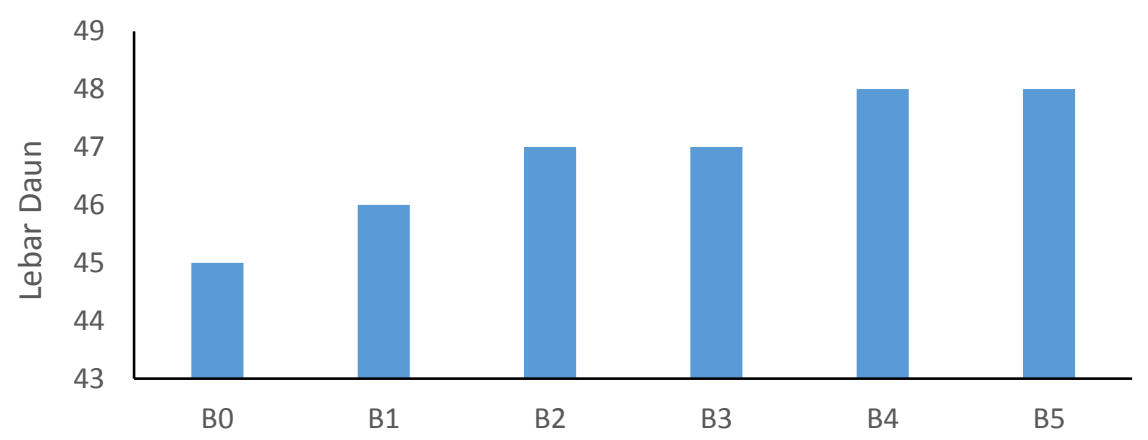

Gambar 4. Rerata Lebar Helaian Daun (mm) Bayam Cabut

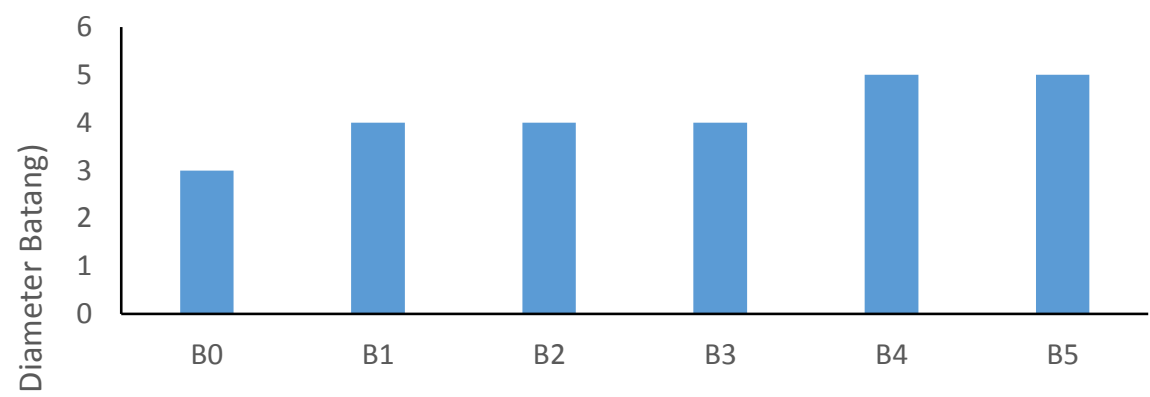

Gambar 5. Rerata Diameter Batang $(\mathrm{mm})$ Bayam Cabut 
Tabel 5. Hasil Analisis Sidik Ragam Pengaruh Dosis Bokashi terhadap Diameter Batang Bayam Cabut

\begin{tabular}{lccccc}
\hline \multicolumn{1}{c}{ S K } & DB & JK & KT & F. Hit & F tabel 5\% \\
\hline Perlakuan & 5 & 7.8 & 1.6 & 5.50 & 2.42 \\
Galat & 30 & 9.2 & 0.3 & & \\
Umum & 35 & 16.9 & 0.5 & & \\
\hline
\end{tabular}

Hasil analisis sidik ragam pada tabel 4 menunjukkan bahwa perbedaan dosis bokashi berpengaruh nyata terhadap meningkatnya lebar helaian daun bayam cabut dengan lebar daun tertinggi terdapat pada perlakuan 1.6 dan $2.0 \mathrm{~kg}$ bokashi dan terendah ditemukan pada perlakuan $0 \mathrm{~kg}$ bokashi per $10 \mathrm{~kg}$ tanah. Selanjutnya rerata diameter batang bayam cabut disajikan pada gambar 5 .

Hasil analisis sidik ragam pada tabel 3 menujukkan bahwa perlakuan bokashi secara signifikan dapat meningkatkan panjang helaian daun bayam cabut dengan panjang daun tertinggi terdapat pada perlakuan $1.6 \mathrm{~kg}$ dan $2.0 \mathrm{~kg}$ bokashi per $10 \mathrm{~kg}$ media tanah. Selanjutnya rerata lebar helaian daun bayam cabut disajikan pada gambar 4 .

Data pada gambar 4 menujukkaan bahwa lebar helaian daun bayam cabut tertinggi adalah 48 $\mathrm{mm}$ terdapat pada perlakuan $\mathrm{B}_{4}$ dan $\mathrm{B}_{5}$ (perlakuan 1.6 dan 2.0 bokashi per $10 \mathrm{~kg}$ tanah). Lebar helaian daun terendah adalah $45 \mathrm{~mm}$ ditemukan pada perlakuan $\mathrm{B}_{0}$ (perlakuan $0 \mathrm{~kg}$ bokashi per $10 \mathrm{~kg}$ media tanah). Hasil analis sidik ragam pengaruh dosis bokashi terhadap lebar helaian daun bayam cabut terdapat pada tabel 4.

Pada gambar 4 dapat dilihat bahwa rerata diameter batang bayam cabut tertinggi adalah $5 \mathrm{~mm}$ terdapat pada perlakuan $\mathrm{B}_{4}$ dan $\mathrm{B}_{5}$ (perlakuan 1.6 dan 2.0 bokashi per $10 \mathrm{~kg}$ tanah. Adapun rerata diameter batang terendah adalah $3 \mathrm{~mm}$ ditemukan pada perlakuan $\mathrm{B}_{0}$ (perlakuan $0 \mathrm{~kg}$ bokashi per $10 \mathrm{~kg}$ media tanah). Selanjutnya hasil analis sidik ragam pengaruh dosis bokashi terhadap diameter batang bayam cabut pada tabel 4 menunjukkan bahwa perlakuan bokashi secara nyata dapat meningkatkan diameter batang bayam cabut putih.

Rerata tinggi batang, panjang helaian daun, lebar helaian daun dan diameter batang bayam cabut bervariasi sesuai dengan dosis perlakuan bokashi. Rerata tinggi batang bayam cabut tertinggi terdapat pada perlakuan $\mathrm{B}_{4}$ (perlakuan $1.6 \mathrm{~kg}$ bokashi per 10 $\mathrm{kg}$ tanah). Selanjutnya rerata panjang helaian daun, lebar helaian daun dan diameter batang bayam cabut tertinggi ditemukan pada perlakuan $\mathrm{B}_{4}$ dan $\mathrm{B}_{5}$ yaitu perlakuan $1.6 \mathrm{~kg}$ dan $2.0 \mathrm{~kg}$ bokashi per $10 \mathrm{~kg}$ tanah.

Adanya pengaruh nyata pemberian bokashi terhadap peningkatan tinggi batang, panjang helaian daun, lebar helaian daun dan diameter batang bayam cabut dimungkinkan karena perlakuan bokashi dapat meningkatkan ketersediaan berbagai unsur hara dalam tanah [1] menemukan bahwa bokashi kotoran burung walet dapat meningkatkan C organik dari 1.92 menjadi 4.79 dengan status sangat tinggi; Fosfor (P) dari 17.05 menjadi 176.82 dengan status sangat tinggi; Kalium (K) dari 23.89 menjadi 78.22 dengan status sangat tinggi pada tanah.. Demikian juga [14] melaporkan bahwa pemberian bokashi dapat meningkatkan P-tersedia pada $60 \mathrm{HSI}$, serta $\mathrm{N}$ total dan $\mathrm{NO}_{3}{ }^{-}$pada 30 dan 60 HSI dibandingkan dengan kontrol.

Tumbuhan mengambil unsur hara dari tanah. Sebagian besar mineral tersedia secara alami di dalam tanah melalui proses pelapukan batuan induk. Namun demikian tidak semua unsur yang diperlukan tumbuhan bersumber dari pelapukan batuan, sebagai contoh unsur fosfor dan nitrogen berasal dari bangkai tumbuhan dan bangkai organisme lainnya di permukaan dan di dalam tanah, setelah melalui proses panjang pengomposan dan penguraian oleh mikroorganisme. Oleh karena itu, komposisi tanah yang paling ideal untuk pertumbuhan dan perkembangan tumbuhan secara normal harus tersedia bahan organik tidak kurang dari 15\%. Bahan organik ini adalah sumber unsur hara Nitrogen dan Fosfor. Dalam hal ini, peran bakteri sebagai pengurai sangat penting sampai unsur hara fosfor dan nitrogen siap untuk diserap oleh tumbuhan. Unsur hara nitrogen juga dapat tersedia secara alami karena peran bakteri dan cyanobakteri tertentu yang mempunyai kemampuan mefiksasi gas nitrogen bebas di atmosfer [4].

Berbagai hasil penelitian lainnya menunjukkan bahwa pemberian bokashi dapat meningkatkan pertumbuhan tanaman. [7] menyimpulkan bahwa pemberian bokashi jerami padi berpengaruh sangat nyata terhadap tinggi semai, diameter batang dan jumlah daun yang telah terbuka dengan sempurna. Pemberian bokashi dengan perbandingan 3:1 untuk pertambahan tinggi semai yaitu $19.26 \mathrm{~cm}$, sedangkan tanpa aplikasi bokashi/kontrol yaitu $11 \mathrm{~cm}$. Pemberian bokashi dengan perbandingan 3:1 untuk pertambahan diameter batang yaitu $0,915 \mathrm{~cm}$, sedangkan tanpa aplikasi bokashi/ kontrol yaitu 0,33 . Pemberian bokashi dengan perbandingan 3:1 untuk pertambahan jumlah daun yaitu 9.8 dan tanpa aplikasi bokashi yaitu 4. Aplikasi bokashi kotoran burung walet menunjukkan pengaruh yang sangat berbeda nyata terhadap pertumbuhan tinggi tanaman cabai merah dan jumlah buah cabai merah. Respon terbaik rata-rata tinggi tanaman $32.12 \mathrm{~cm}$; rata-rata jumlah buah/tanaman 3.00. Aplikasi bokashi kotoran burung walet dengan dosis $200 \mathrm{~g}$ polybag adalah 
dosis terbaik terhadap pertumbuhan tanaman cabai merah [1].

Sejalan dengan hasil penelitian diatas, [9] menyimpulkan bahwa perlakuan bokashi berpengaruh nyata terhadap pertumbuhan dan hasil kacang panjang, dosis optimum bokashi untuk tanaman kacang panjang adalah 1,2 kg bokashi per $1 \mathrm{~m}^{2}$ lahan. Pemberian berbagai jenis bokashi memberikan pengaruh yang sangat nyata terhadap pertumbuhan dan hasil jagung manis, pemberian bokashi daun Johar memberikan hasil yang lebih baik terhadap pertumbuhan jagung manis, sedangkan pemberia bokashi daun Gamal memberikan hasil yang lebih baik terhadap produksi jagung manis [3]. Pemberian bokashi berpengaruh nyata terhadap pertumbuhan dan produksi tomat pada lahan pertanian Desa Pijot [11]. Pertumbuhan dan produksi tanaman tomat terbaik di jumpai pada perlakuan interaksi varietas Betavila F1 dan dosis pupuk bokashi kotoran ayam 15 ton/ha. Perlakuan varietas terbaik pada pertumbuhan dan produksi tanaman tomat di jumpai pada varietas Betavila. Perlakuan dosis pupuk bokashi kotoran ayam terbaik pada pertumbuhan dan produksi tanaman tomat di jumpai pada dosis pupuk 15 ton per hektar [13].

\section{KESIMPULAN}

Berdasar hasil analisis data dan pembahasan pada penlitian ini dapat sisimpulkan: (1) aplikasi bokashi berpengaruh nyata terhadap tinggi batang, panjang daun, lebar daun dan diameter batang tetapi tidak berpengaruh nyata terhadap jumlah daun bayam cabut, (2) dosis optimum bokashi yang perlu diberikan pada lahan pertanian Desa Bajur untuk meningkatkan pertumbuhan bayam cabut adalah 1.6 $\mathrm{kg}$ per $10 \mathrm{~kg}$ tanah.

\section{DAFTAR PUSTAKA}

[1] Alfionita,R., R.R. Paranoan dan R. Kusumaningwati. (2018). Pemberian Bokashi Kotoran Walet Terhadap Beberapa Sifat Kimia Tanah dan Pertumbuhan Serta Hasil Tanaman Cabai Merah (Capsicum annum L.). Agroekoteknologi Tropika Lembab. Vol. 1 (1): 43 $-52$

[2] Gomez K.A. dan A.A. Gomez. (1995). Prosedur Statistik Untuk penelitian Pertanian. Edisi Kedua Penerjemah: Endang Syamsudin dan Justika S. Baharsyah. UI Press. Jakarta.

[3] Hasibuan, S., Mawarni, R., Hendriandri, R. (2017). Respon Pemberian Pupuk Bokashi Ampas Tebu dan Pupuk Bokashi Eceng Gondok terhadap Pertumbuhan dan Produksi Tanaman Kedelai. Bernas 13(2) p. 59-64

[4] Knox, B., P. Ladiges, B. Evans. (1994). Biology. McGraw-Hill Book Company Australia Pty Limited. Australia.
[5] Mulyana, D., Sahidin dan Iqbal, A. (2011). Pengaruh Dosis Bokashi terhadap Pertumbuhan dan Hasil Tiga Varietas Padi. Agrin Vol 15(1) p. $18-26$

[6] Mulyanti, S.S., Made, U. dan Wahyudi, I. (2015). Pengaruh Pemberian Berbagai Jenis Bokashi terhadap Pertumbuhan dan Hasil Jagung Manis (Zea mays Saccarata). Agrotekbis 3(5): 592 - 601

[7] Nismawati, R. Wulan dan Irmasari. (2013). Pengaruh Pemberian Berbagai Dosis Bokashi terhadap Pertumbuhan Semai Kemiri (Aleurites moluccana L. Willd.). Warta Rimba. Vol 1 (1): 18

[8] Raksun, A dan L. Japa (2019). Pengaruh Bokashi dan Pupuk NPK terhadap Pertumbuhan dan Hasil Kacang panjang. Pijar MIPA Vol 20 (20): $8-11$

[9] Raksun, A dan L. Japa (2019). Pengaruh Jenis Mulsa dan Dosis Bokashi terhadap Pertumbuhan Kacang Panjang. Jurnal Penelitian Pendidikan IPA Vol. 5 (1): 34 - 38

[10] Raksun, A dan I.G. Mertha. 2017. Pengaruh Bokashi Terhadap Produksi Cabai Rawit (Capsicum annuum). Biologi Tropis Vol: 17 (2): $45-50$

[11] Rakun, A. dan Santoso D. 2010. Pemanfaatan Bokashi untuk Meningkatkan Pertumbuhan dan Produksi Tomat (Lycopersicum esculentum). Biologi Tropis 11 (1): 44 - 50

[12]Raksun .A. Mahrus dan I.G. Mertha. 2019. Pengaruh Jenis Mulsa dan Dosis Bokashi Terhadap Pertumbuhan Cabai Rawit (Capsicum frutescens L.). Jurnal Penelitian Pendidikan IPA. Vol:6 (1): $57-62$

[13] Sahetapy, M. M., Pongoh, J., Tilaar, W. 2017.Analisis Pengaruh Beberapa Dosis Pupuk Bokashi Kotoran Ayam terhadap Pertumbuhan dan Produksi Tiga Varietas Tomat (Solanum lycopersicum L.) Di Desa Airmadidi. AgriSosioEkonomi Unsrat. Vol. 13 (2): 70 - 82

[14] Setyastika, U.S. dan R. Suntari. 2019. Pengaruh Aplikasi Bokashi terhadap Dinamik Ketersediaan N, P dan S pada Inceptisol Karangploso Malang. Jurnal Tanah dan Sumberdaya Lahan. Vol. 6 (2): 1291 - 1299.

[15] Sunarjono, 2006. Kunci Bercocok Tanam Sayur- Sayuran Penting Di Indonesia. Sinar Baru. Bandung.

[16] Teutenburg, H. and Shalabh. 2009. Statistical Analysis of Designed Experiment. Third Edition. Springer. New York

[17] Yuliatri, N. 2009. Cara Menghasilkan Pupuk Organik. Lily Publisher. Yogyakarta.

[18]Zulkarnain. H. 2014. Dasar-Dasar Hortikultura. Bumi Aksara. Jakarta. 